\title{
Correction to: Towards the restoration of the Mesoamerican Biological Corridor for large mammals in Panama: comparing multi-species occupancy to movement models
}

Ninon F. V. Meyer ${ }^{1,2,3^{*}}$, Ricardo Moreno ${ }^{3,4}$, Rafael Reyna-Hurtado ${ }^{1}$, Johannes Signer ${ }^{2}$ and Niko Balkenhol ${ }^{2}$

Correction to: Mov Ecol (2020) 8:3

https://doi.org/10.1186/s40462-019-0186-0

Following publication of the original article [1], the authors identified an error in the second equation in the 'Estimating the resistance' section due to a typesetting mistake: 9 should be replaced by 99 . The correct equation is given below and the original article has been corrected.

$$
R=100-99 \frac{\left(1-e^{(-c * H S)}\right)}{\left(1-e^{-c}\right)}
$$

The publisher apologises to the authors and readers for the inconvenience.

\section{Author details}

'Departamento de Conservación de la Biodiversidad, El Colegio de la Frontera Sur, Lerma, Campeche, Mexico. ${ }^{2}$ Wild life Sciences, Faculty of Forest Sciences, University of Göttingen, Göttingen, Germany. ${ }^{3}$ Fundación Yaguará Panamá, Ciudad del Saber, Panama. ${ }^{4}$ Smithsonian Tropical Research Institute, Balboa, Ancón, Panama.
Published online: 26 May 2020

\section{Reference}

1. Meyer NFV, Moreno R, Reyna-Hurtado R, Signer J, Balkenhol N. Towards the restoration of the Mesoamerican biological corridor for large mammals in Panama: comparing multi-species occupancy to movement models. Mov Ecol. 2020;8:3. https://doi.org/10.1186/s40462-019-0186-0.

The original article can be found online at https://doi.org/10.1186/s40462019-0186-0.

* Correspondence: ninonmeyer@gmail.com

'Departamento de Conservación de la Biodiversidad, El Colegio de la Frontera Sur, Lerma, Campeche, Mexico

${ }^{2}$ Wildlife Sciences, Faculty of Forest Sciences, University of Göttingen, Göttingen, Germany

Full list of author information is available at the end of the article

C C The Author(s). 2020 Open Access This article is licensed under a Creative Commons Attribution 4.0 International License, which permits use, sharing, adaptation, distribution and reproduction in any medium or format, as long as you give appropriate credit to the original author(s) and the source, provide a link to the Creative Commons licence, and indicate if changes were made. The images or other third party material in this article are included in the article's Creative Commons licence, unless indicated otherwise in a credit line to the material. If material is not included in the article's Creative Commons licence and your intended use is not permitted by statutory regulation or exceeds the permitted use, you will need to obtain permission directly from the copyright holder. To view a copy of this licence, visit http://creativecommons.org/licenses/by/4.0/ The Creative Commons Public Domain Dedication waiver (http://creativecommons.org/publicdomain/zero/1.0/) applies to the data made available in this article, unless otherwise stated in a credit line to the data. 